
Australian Journal of
Crop Science

\title{
Gas exchange and antioxidant activity accessions of Jatropha curcas $L$. under aluminium (Al) stress
}

\author{
Leandro Henrique de Souza Mota ${ }^{1}$, Silvana de Paula Quintão Scalon ${ }^{2 *}$, Daiane Mugnol Dresch ${ }^{2}$, Lourenço Quintão \\ Scalon ${ }^{2}$, César José da Silva ${ }^{3}$ \\ ${ }^{1}$ Syngenta, Cascavel, State Paraná, Brazil \\ ${ }^{2}$ Faculty of Agricultural Sciences, Federal Universty of Grande Dourados, Road Dourados Itahum, km12, Rural \\ Subdivision, CEP: 79804970, Dourados, State Mato Grosso do Sul, Brazil \\ ${ }^{3}$ Brazilian Agricultural Research Corporation Dourados, State Mato Grosso do Sul, Brazil
}

*Corresponding author: silvanascalon@ufgd.edu.br

\section{Abstract}

The aluminium at toxic levels causes biochemical and physiological damage that inhibits plant growth and limits productivity. Root growth, chlorophyll a fluorescence, and enzyme activity of four accessions of Jatropha curcas were evaluated under cultivation conditions with different levels of aluminium. The experimental design was completely randomized with a split-split-plot design, in which the plots included four levels of aluminium in the soil $\left(0.0,8.2,16.5\right.$, and $\left.24.0 \mathrm{mmol}_{\mathrm{c}} \mathrm{dm}^{-3}\right)$, the split-plot were the four accessions of $J$. curcas seeds (P1 = Dourados, MS; P2 = Montes Claros, MG; P3 = Alta Floresta, MT; P4 = Petrolina, PE), and split-split-plot in all four times of evaluation $(25,50,75$, and 100 days after emergence - DAE) with four replications. At 100 DAE were evaluated the curve of transient chlorophyll a fluorescence (OJIP) and enzyme activity, the treatments were arranged in split-plot, being four levels of aluminium in the soil and the four accesses of J. curcas. Six readings for the OJIP curve and three repetitions for enzymatic analysis were conducted. The characteristics of gas exchange and chlorophyll a fluorescence indicated that doses above 8.2 accentuated aluminium stress on plants from all accessions. The reduced efficiency of carboxylation of Rubisco and the results of the OJIP test indicated that photochemical efficiency of all varieties was decreased. The activity of the enzymes catalase, peroxidase, and superoxide dismutase was higher in the presence of aluminium for the accessions P3-Alta Floresta and P4-Petrolina. Our results indicate the greater tolerance of these accesses to aluminium stress conditions.

Keywords: aluminium stress, antioxidant enzymes, photosynthesis.

\section{Introduction}

Jatropha curcas, also known as purging nut, is a plant cultivated for oil and food that is not very productive in tropical and subtropical areas. Drought resistant species are well adapted to semi-arid conditions, although these species show better performance under more humid conditions and can grow where most other crops cannot survive. The oil content of the seeds is $25 \%-32 \%$, with yields of 1.5 tons of oil per hectare after 5 years of growth. J. curcas is grown in Central and South America, Southeast Asia, India, and Africa economic purposes (Achten et al., 2010; Behera et al., 2010; Pompelli et al., 2010a; Pompelli et al., 2010b).

This species shows wide genetic diversity because of the lack of defined varieties, spread of the seed, and high rates of cross-pollination. The cultivation of $J$. curcas has been suggested as an important alternative energy source, as it provides oil supply for the manufacture of biodiesel.
Cultivation of J. curcas has expanded to the Cerrado region of Brazil, where the soil presents fertility problems as well as high acidity, which favors the availability of aluminium at levels that may be toxic to plants (Konrad et al., 2005).

Aluminium can cause damage to plants by reducing growth as a result of decreased photosynthetic activity. In some species, aluminium toxicity can markedly decreased estomatal conductance. Aluminium also causes prevents the formation and function of chloroplasts, affecting thylakoid membranes and electron transport, inhibiting photosystem II (PSII) activity, and leading to decreased chlorophyll fluorescence (Konrad et al., 2005; Peixoto et al., 2002; Cupertino et al., 2016).

The fluorescence yield of chlorophyll indicates the level of excitation energy in the pigment system that drives photosynthesis and provides a means for estimating the 
inhibition or damage in the process of electron transfer from photosystem II (Bolhàr-Nordenkampf, 1989).

The quantum efficiency of photosystem II (variable fluorescence/maximum fluorescence $-F_{v} / F_{m}$ ) represents and reflects the efficiency with which light is absorbed by the photosystem II antenna complex. This light energy is converted into chemical energy, and $F_{v} / F_{m}$ can thus be used to detect disturbances in the photosynthetic system caused by environmental and biotic stresses, a decrease in $F_{v} / F_{m}$ indicates the inhibition of photochemical activity.

Aluminium exposure induces the formation of reactive oxygen species in cells, leading to oxidative stress and tolerance by plants to this element; these activities are mediated by the activity of antioxidant systems. The major enzymes involved in the homeostatic control of $\mathrm{H}_{2} \mathrm{O}_{2}, \mathrm{OH}$, and $\mathrm{O}_{2}$ levels during plant metabolism in different cellular compartments such as the chloroplast, mitochondria, peroxisome, and apoplast include superoxide dismutase (SOD), catalase (CAT), peroxidase (POX), and ascorbate peroxidase (Ma et al., 2012; Xu et al., 2012; Ribeiro et al., 2012).

Considering the information in the literature that several species may show damage to the photosynthetic activity as a result of the exposure of the roots to aluminium, hypothesize that the photosynthetic metabolism of Jatropha curcas from different accessions different sensitivity to varying feature levels of aluminium in the soil, which can be attributed to efficiency of antioxidant enzymes. The objective of the present study was to evaluate the morphophysiological responses of accessions of $J$. curcas to represent four towns in different regions of Brazil in the presence of different levels of aluminium.

\section{Results and Discussion}

\section{Root growth}

As increased levels of aluminium, root length decreased occurred (Figure 1a) and the values were superior to 100 days after emergence (DAS) (Figure 1b). The root volume, was superior to the origin $\mathrm{P} 1$ in the conditions of absence of aluminium and reduced with high aluminium levels in the soil. At levels greater than $8.2 \mathrm{mmol}_{\mathrm{c}} \mathrm{dm}^{-3}$ of aluminium in the soil, the plants of origin P4 presented more root volume (13.93 $\mathrm{cm}^{3}$ ) at concentration maximum $11 \mathrm{mmol}_{\mathrm{c}} \mathrm{dm}^{-3}$ aluminium (Fig 1c). The root volume increased linearly along the evaluations in all aluminium concentrations studied, being greater in the absence $(0.0)$ and $8.2 \mathrm{mmol}_{\mathrm{c}} \mathrm{dm}^{-3}$ with averages very close to the end of the evaluations (Fig. 1d).

The lower growth and root volume, due to the presence of aluminium, resulting in less uptake of water and nutrients that are essential to compose molecules essential for the photosynthetic process. Several biochemical and physiological processes can be changed before the root growth inhibition induced by aluminium, among them photosynthetic activity and oxidative stress (Yamamoto et al., 2002).

Similar results were obtained by (Macedo et al., 2011), evaluating the effect of aluminium on Jatropha plants, observed a linear reduction of root length as increased aluminium levels. It is suggested that the aluminium would react with polygalacturonic acid chains from the walls of young cells, forming compounds accumulating pectic substances "wrong" (replacement or displacement of $\mathrm{Ca}$ which would result in the loss of elasticity cell.

\section{Gas exchange}

Instant carboxylation efficiency $(A / C i)$ and intrinsic water use efficiency (IWUE $-A / g s$ ) showed a linear reduction with increasing aluminium levels (Figure $2 \mathrm{a}$ and $2 \mathrm{c}$ ) and with an increasing number of days after emergence (Figure $2 b$ and $2 d$ ). Over time, the ratio of IWUE was higher in the absence of aluminium and $8.2 \mathrm{mmol}_{\mathrm{c}} \mathrm{dm}^{-3}$, being presented in these treatments increased relationship until the 80 days after emergence (Figure $2 \mathrm{~b}$ ), and with an increasing number of days after emergence (Figure $2 \mathrm{~d}$ ).

The reduction of $A / C i$ and IWUE is due to the lower photosynthetic rate $(A)$ and stomatal conductance $(g s)$ (data not shown), and the reduction of stomatal conductance is one of the factors responsible for the decrease in the photosynthetic rate of the plants.

The reduction of $A / C i$ in the presence of aluminium was also observed for Konrad et al. (2005) in a study evaluating the effect of aluminium stress in six varieties of coffee. Their results also showed significantly lower instant efficiency values for carboxylation in plants subjected to stress.

In review Yang et al. (2015) observed that in several species the toxicity of $\mathrm{Al} 3+$ may cause a decrease in stomatal conductance and chlorophyll content, in electron transport is inhibited and the photosynthetic rate usually declines, besides affecting the roots of plants, but transpiration and water use efficiency not always reduce. The authors verified that the Al toxicity symptoms in photosynthetic activity has a close linkage with Al concentration in environments. In a manner similar Hevea brasiliense L. showed increased stomatal resistance, reducing the number and stomatal opening and transpiration (Cupertino et al., 2016).

\section{Chlorophyll fluorescence}

The quantum efficiency of photosystem II $\left(\mathrm{F}_{\mathrm{v}} / \mathrm{F}_{\mathrm{m}}\right)$ of J. curcas plants decreased linearly with the presence of aluminium (Figure 2c). In contrast, there was no significant effect of time, and the estimated value of the dependent variables was equal to the arithmetical average obtained in the test, which was 0.78 (Figure $2 \mathrm{~d}$ ). The quantum efficiency of photosystem II $\left(F_{v} / F_{m}\right)$ has been used frequently to detect disturbances in photosynthetic systems cause by environmental and biotic stresses, where in a decrease in this value indicates the inhibition of photochemical activity. Values of $F_{v} / F_{m}$ to 0.8 indicate a maximum efficiency in energy use in the photochemical process, while values below 0.75 indicate a stress situation in which the photosynthetic potential of the plant is reduced (Mehta et al., 2010). In studies of Sorghum bicolor L (Peixoto et al., 2002) and $H$. brasiliensis L. (Cupertino et al., 2016), comparing tolerant and aluminium-sensitive species and cultivars, the authors observed significant reductions in $F_{v} / F_{m}$ and $F 0$ in sensitive plants. In a study by 
A)

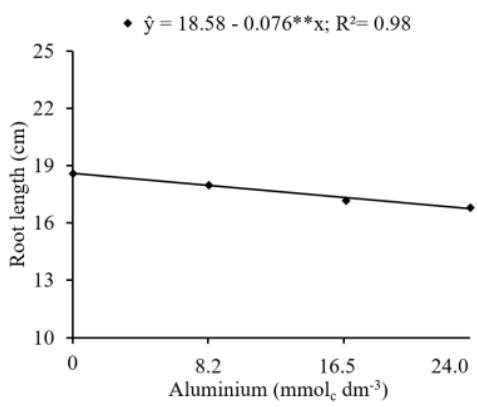

C)

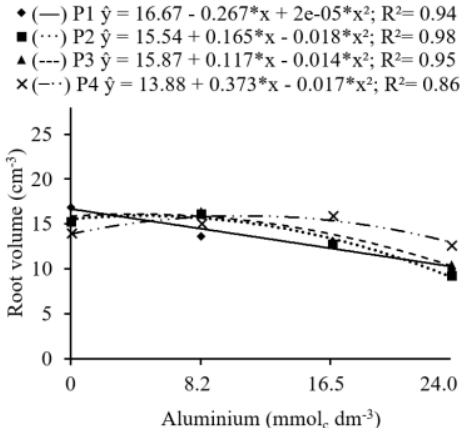

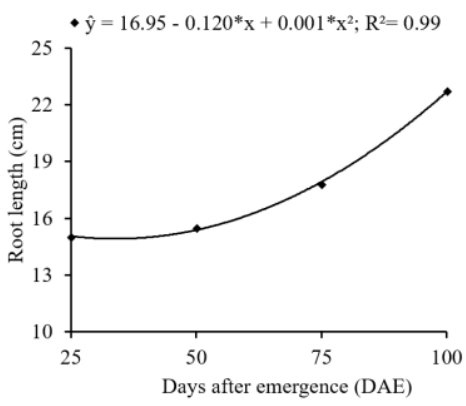

D)

$\bullet(-)$ Al $0 \quad \hat{y}=-2.666+0.282 * x ; R^{2}=0.96$

-() Al $8.2 \hat{y}=-1.454+0.261 * x ; R^{2}=0.91$

^(--) Al $16.5 \hat{y}=-1.104+0.227^{* *} \mathrm{x} ; \mathrm{R}^{2}=0.97$

$\times(-\cdot) \mathrm{Al} 24.0 \hat{\mathrm{y}}=0.354+0.156^{*} \mathrm{x} ; \mathrm{R}^{2}=0.92$

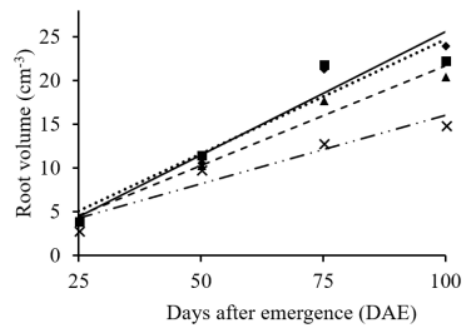

Fig 1. Root length $(\mathrm{cm})(\mathrm{a}, \mathrm{b})$ and root volume $\left(\mathrm{cm}^{-3}\right)(\mathrm{c}, \mathrm{d})$ of plants Jatropha curcas $\mathrm{L}$. in function of different levels of aluminium in the soil $(0.0 ; 8.2 ; 16.5$ and $\left.24.0 \mathrm{mmol}_{\mathrm{c}} \mathrm{dm}^{-3}\right)$ and days after emergence (DAE) (25, 50, 75 and 100).

a)

- $\hat{y}=50,40-1,045^{* * *} \mathrm{x} ; \mathrm{R}^{2}=0,98$

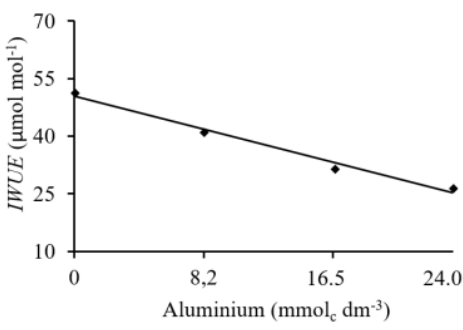

c)

$\Delta(-) \mathrm{A} / \mathrm{Ci} \quad \hat{\mathrm{y}}=0.056-0.0009{ }^{* *} \mathrm{x} ; \mathrm{R}^{2}=0.97$

- (- -) Fv/Fm $\hat{y}=293.8-0.722 * x ; R^{2}=0.80$

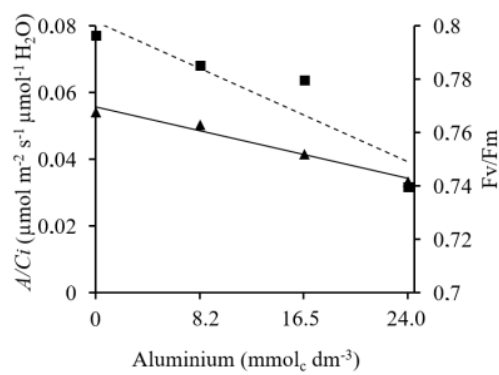

b)

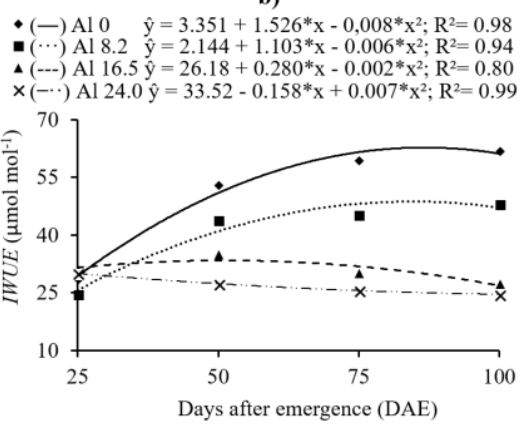

d)

$\Delta\left(\right.$ ( ) $\mathrm{A} / \mathrm{Ci} \quad \hat{\mathrm{y}}=0.059-0.0002 * \mathrm{x} ; \mathrm{R}^{2}=0.96$

- (- -) Fv/Fm $\hat{y}=\bar{y}=0.78$

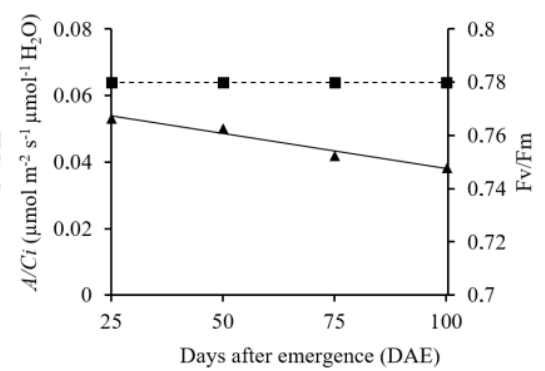

Fig 2. Intrinsic water use efficiency (IWUE - $A / g s)(a, b)$, instant carboxylation efficiency $(A / C i)$ and quantum efficiency of photosystem II $\left(F_{v} / F_{m}\right)(c, d)$ of plants Jatropha curcas L. in function of different levels of aluminium in the soil $\left(0.0 ; 8.2 ; 16.5\right.$ and $\left.24.0 \mathrm{mmol}_{\mathrm{c}} \mathrm{dm}^{-3}\right)$ and days after emergence (DAE) (25, 50,75 and 100). 

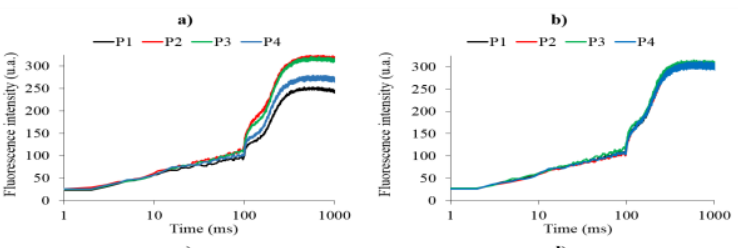

c)
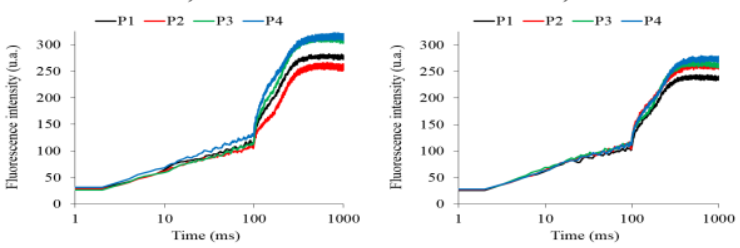

-Al $-\mathrm{Al} 8.2 \stackrel{\text { e) }}{-} \mathrm{Al} 16.5-\mathrm{Al} 24.0$

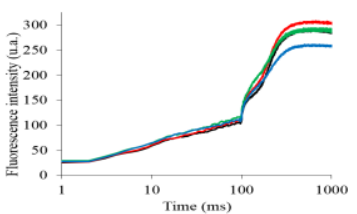

Fig 3 Curve of chlorophyll $a$ fluorescence the 100 days after emergency of plants Jatropha curcas L. in function of different accessions (P1 = Dourados, MS; P2 = Montes Claros, MG; P3 = Alta Floresta, MT; P4 = Petrolina, PE) in thelevels of aluminium in the soil 0.0 (a), 8.2 (b) 16.5 (c) and 24.0 (d) mmolc $\mathrm{dm}^{-3}$ and according to the doses of aluminium (e).

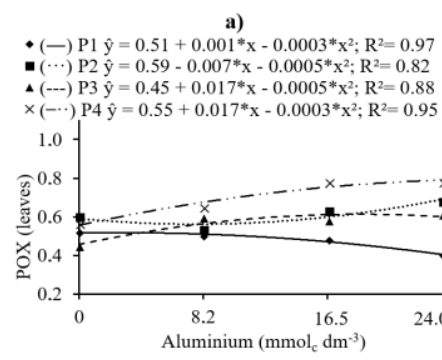

c)

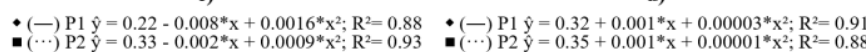

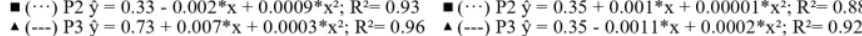

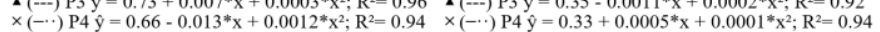

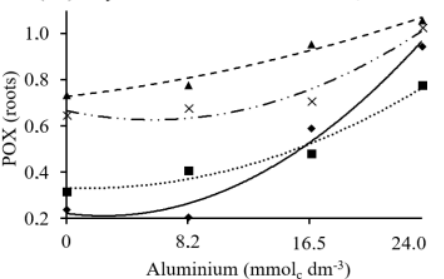

b)

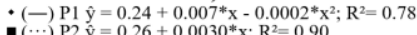

- () $\mathrm{P} 2 \hat{\mathrm{y}}=0.26+0.0030^{*} \mathrm{x} ; \mathrm{R}^{2}=0.90$

(--) $\mathrm{P} 3 \mathrm{y}=0.24+0.005 \mathrm{x}-0.0001 \mathrm{x}^{2} ; \mathrm{R}^{2}=0.73$

$\times(-\cdot) \mathrm{P} 4 \hat{\mathrm{y}}=0.30-0.008^{*} \mathrm{x}-0.0003^{*} \mathrm{x}^{2} ; \mathrm{R}^{2}=0.98$

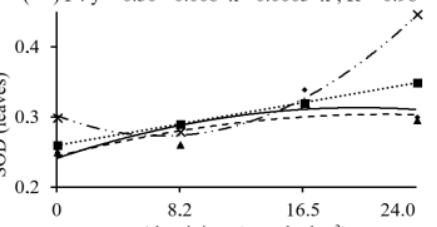

(1)

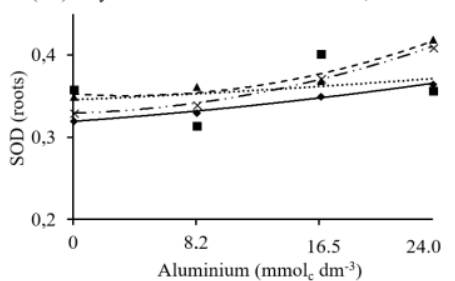

e)

- (一) $\mathrm{P} 1 \hat{\mathrm{y}}=0.02+0.0005 * \mathrm{x}-0.00002^{*} \mathrm{x}^{2} ; \mathrm{R}^{2}=0.96$ - (․) P2 $\hat{y}=0.02-0.0002^{*} \mathrm{x}+0.00001^{*} \mathrm{x}^{2} ; \mathrm{R}^{2}=0.97$ $\Delta(---) \mathrm{P} 3 \hat{\mathrm{y}}=0.03-0.0006^{*} \mathrm{x}+0.00003^{*} \mathrm{x}^{2} ; \mathrm{R}^{2}=0.87$ $\times(-\cdots) \mathrm{P} 4 \hat{\mathrm{y}}=0.02+0.0009^{*} \mathrm{x}-0.00002^{*} \mathrm{x}^{2} ; \mathrm{R}^{2}=0.98$

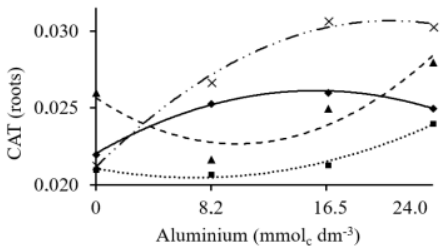

Fig 4 Enzimatic activity of peroxidase in leaves (POD - M guaiacol $\min ^{-1} \mathrm{~g}$ fresh matter ${ }^{-1}$ ) (a) and roots (c), superoxide dismutase in leaves (SOD - units $\mathrm{mg}$ ${ }^{1}$ fresh matter ${ }^{-1}$ ) (b) and roots (d) of catalase in roots (e) (CAT - mM guaiacol $\mathrm{min}^{-1}$ fresh matter ${ }^{-1}$ ) of Jatropha curcas L. in function of different accessions in Brazil (P1 = Dourados, MS; P2 = Montes Claros, MG; P3 = Alta Floresta, MT; P4 = Petrolina, PE) in the levels of aluminium in the soil (0.0, 8.2, 16.5 and $24.0 \mathrm{mmol}_{\mathrm{c}} \mathrm{dm}^{-3}$. 
Konrad et al. (2005), who analyzed gas exchange and fluorescence in Coffea arabica L. plants, the $F_{v} / F_{m}$ of the cultivars was decreased by $13 \%$ in the presence of aluminium $\left(0.148 \mathrm{mmol} \mathrm{L}^{-1}\right)$.

In $8.2 \mathrm{mmol}_{\mathrm{C}} \mathrm{dm}^{-3}$ aluminium in the transient OJIP curves of the accessions showed very similar behavior, indicating that there was no variation in photochemical efficiency (Figure 3a).

In contrast, for 16.5 and $24.0 \mathrm{mmol}_{\mathrm{c}} \mathrm{dm}^{-3}$, the accessions P3 and P4 showed a larger area above the curve of fluorescence, indicating more efficient photochemistry compared to other genotypes (Figure $3 \mathrm{c}$ and $3 \mathrm{~d}$ ). The level of $24.0 \mathrm{mmol}_{\mathrm{c}} \mathrm{dm}^{-3}$ of aluminium in the soil decreased fluorescence intensity, as observed for the transient OJIP modification (Figure 3d).

The various accessions of J. curcas showed a typical OJIP curve of chlorophyll fluorescence for the aluminium levels measured (Figure 3e). Comparison of transient OJIP shows that the P2 and $\mathrm{P} 3$ genotypes had increased values for the area above the curve, indicating more efficient photochemistry.

The OJIP of chlorophyll fluorescence was determined to verify that the results reflected the behavior of plants according to the doses of aluminium. Plants subjected to $24.0 \mathrm{mmol}_{\mathrm{c}} \mathrm{dm}^{-3}$ aluminium showed fewer sigmoidal curves compared with the OJIP for other transient levels (Figure 3e). The area above the OJIP curve between $F_{0}$ and $F_{m}$ is proportional to the oxidation state of the electron acceptors on the PSII reducer and inversely proportional to the state of reduction (Mehta et al, 2010). A larger area indicates greater transfer of electrons from the reaction center for the 'pool' of plastoquinone.

This is because quinone-mediated re-oxidation is more efficient in inducing the excited electron transport photosystem I (Oukarroum et al., 2009). Thus, the OJIP curves revealed that at the highest concentration of aluminium, $J$. curcas might have had a lower capacity for consequent reoxidation of QA in PSII. This may have resulted in QA accumulation and, consequently, reduced transport of electrons. This is reflected in the PSI, the final electron acceptor (Silva et al., 2011).

\section{Activity antioxidant enzymes}

With respect to the enzyme activity test, in the analysis of the enzyme CAT in shoots, there was no significant effect ( $p>$ 0.05 ) on the accessions of the aluminium levels evaluated. Thus, averages were not compared or adjusted using characteristic regression equations, as the estimated value of the dependent variables was equal to the arithmetical average obtained in the assay $\left(0.057 \mathrm{mM}\right.$ guaiacol $\mathrm{min}^{-1} \mathrm{~g}$ fresh matter $\left.{ }^{1}\right)$.

With the exception of accessions 1, POX enzyme activity increased in J. curcas with increasing aluminium levels in the soil, with the highest levels of enzyme activity observed in origin P4. Already the P1 origin had a different behavior, since the activity decreased with increasing aluminium concentration (Figure 4a).

The activity of the enzyme SOD in leaves showed similar behavior to the enzyme POX, with elevated enzyme activity at increasing levels of aluminium. However, the accessions showed no large differences until the concentration of 16.4 $\mathrm{mmol}_{\mathrm{c}} \mathrm{dm}^{-3}$ was reached. Most enzyme activities were higher in accessions P4 (Figure 4b). POX enzyme activity generally increased at elevated aluminium levels, and P3 showed the highest values for POX activity at all levels assessed (Figure 4c). The activity of the enzyme SOD in the roots was similar to the behavior observed in the leaves of $J$. curcas, in which the values differed at the concentration of $16.4 \mathrm{mmol}_{\mathrm{c}} \mathrm{dm}^{-3}$; however, at levels above this value, accessions P3 and P4 showed higher enzyme activity (Figure $4 \mathrm{~d}$ ). These results indicate that accessions P3 and P4 were tolerant to aluminium, with greater efficiency in absorbing water and nutrients.

In the root system of J. curcas, we observed that CAT activity was higher than in P3 in the absence of aluminium, but with elevated aluminium levels in the soil, activity was reduced to $10.5 \mathrm{mmol}_{\mathrm{c}} \mathrm{dm}^{-3}$. At levels greater than $4.0 \mathrm{mmol}_{\mathrm{c}} \mathrm{dm}^{-3}$ aluminium in the soil, the plants of provenance P4 showed higher enzyme activity in roots (Figure 4e).

Increased tolerance to stress is strongly related to increased antioxidant system activity in plants (Ma et al., 2012; Xu et al, 2012; Ribeiro et al., 2012). For example, the level of expression of proteins such as CAT, POX, and SOD increase. The increased activity of enzymes in response to aluminium exposure probably helps to lower lipid peroxidation and protect the photosynthetic apparatus.

The effect of aluminium stress on the activity of antioxidant enzymes was observed in the literature for other species. Similar results to those observed for $J$. curcas were observed for Oryza sativa cultivars (Ma et al., 2012; Xu et al., 2012) and Triticum aestivum (Ribeiro et al., 2012). CAT activity in rice roots increased more in sensitive than in tolerant cultivars but remained greater in tolerant cultivars. Values in the leaves varied between the two cultivars. POX activity increased more in the sensitive cultivar.

SOD activity increased by $17 \%$ in the aluminium-tolerant cultivar but not in the roots of the sensitive cultivar. There was an $11 \%$ reduction in the leaves of the sensitive but not the tolerant cultivar.

\section{Materials and Methods}

\section{Study area}

The experiment was conducted in a greenhouse covered with low-density polyethylene at the Faculty of Agricultural Sciences at the Federal University of Grande Dourados, located in the municipality of Dourados, Mato Grosso do Sul, Brazil.

The experiment was conducted at latitude $22^{\circ} 11^{\prime} 45^{\prime \prime} \mathrm{S}$ and longitude $54^{\circ} 55^{\prime} 18^{\prime \prime} \mathrm{W}, 446 \mathrm{~m}$ above sea level. The climate of the region is classified as type Cwa (Köppen) with humid, hot summers and dry winters (Fietz e Fisch, 2006).

\section{Plant and cultivation material}

The experimental unit was formed from plants in pots with capacities of $5.0 \mathrm{dm}^{3}$ of soil. After collection, the soil was airdried and sieved through ha $5-\mathrm{mm}$ mesh to remove lumps. The soil used in the present study was classified as Red Latosol Distroferric clay texture and was collected from a depth of 80$100 \mathrm{~cm}$. 


\section{Treatments}

Different levels of aluminium in the soil were prepared by initial soil correction (Al 1), with an aluminium concentration of $24.0 \mathrm{mmol}_{\mathrm{c}} \mathrm{dm}^{-3}$. The correction was carried out using limestone "filler" to increase the soil base saturation levels to 33.3\% ( $\mathrm{Al} \mathrm{2}$ ), 56.6\% ( $\mathrm{Al} \mathrm{3)}$, and 80\% ( $\mathrm{Al} \mathrm{4)}$, with limestone doses corresponding to $0.48,0.97$, and $1.65 \mathrm{~g} \mathrm{~kg}^{-1}$, respectively. To calculate the amount of aluminium required for correction, we used the method of saturation by 19 bases. At the end of the incubation, soil samples $\mathrm{Al} 2, \mathrm{Al} 3$, and $\mathrm{Al} 4$ were subjected to chemical analysis and aluminium concentrations were found to be $16.0,8.2$, and $0.0 \mathrm{mmol}_{c} \mathrm{dm}^{-3}$, respectively. The initial soil Al $1\left(24.0 \mathrm{mmol}_{\mathrm{c}} \mathrm{dm}^{-3}\right)$ was used to prepare the experimental plots.

Quantification was performed using aluminium 1 molar $\mathrm{KCl}$ Extractor, bromothymol blue indicator, and titration with $0.025 \mathrm{M} \mathrm{NaOH}$. Fertilization was performed based on published recommendations for growth in controlled environments as described previously by Novais et al. (1991).

The soil from each pot and the appropriate amount of limestone were placed in a plastic bag with a capacity of $20 \mathrm{~L}$, which was inflated with air and shaken vigorously for $1 \mathrm{~min}$. Next, the soil was moistened with water in order to occupy approximately $80 \%$ of the water holding capacity (WHC). The bags were partially closed to reduce water loss by evaporation and incubated for 30 days. Every 10 days, the soils were moved to dissipate the $\mathrm{CO}_{2}$ released by the reaction of limestone, and the humidity was restored to $80 \%$ WHC.

The seeding of four accessions was conducted soon after fertilization, with eight seeds per pot at a depth of $3 \mathrm{~cm}$. Plant thinning was conducted on the 12th day after sowing to reduce the number of plants to two per pot. The vessels were kept at the same humidity $(80 \%$ WHC) throughout the experiment. The amount of evaporated water was determined by weighing the vessels daily, and lost water content was replaced.

\section{Evaluations}

The root length was analysed using a ruler graduated in millimeters for the measurement of the largest root. The root volume was obtained by placing the roots in measuring cylinder, containing a known volume of water, being retrieved from the root volume by difference, in which considered the equivalence of units $\left(1 \mathrm{ml}=1 \mathrm{~cm}^{3}\right)$.

Gas exchange and chlorophyll fluorescence were determined every 25 days post-emergence $(25,50,75$, and 100 days).

The carboxylation efficiency $\left(A / C i, \mu \mathrm{mol} \mathrm{m}^{-2} \mathrm{~s}^{-1} \mu \mathrm{mol} \mathrm{mol}^{-1}\right)$ and intrinsic water use efficiency (IWUE-A/gs $\mu$ molCO$_{2} \mathrm{~mol} \mathrm{H}_{2} \mathrm{O}$ ) were quantified using an infrared gas analyzer (IRGA - ADC model LCi PRO Analytical Development Co Ltd., Hoddesdon, UK). The potential quantum efficiency of photosystem II (Fv/Fm) obtained from chlorophyll $a$ fluorescence data, were measured using the portable fluorometer model OS-30p (OptiSciences Chlorophyll Fluorometer), Hudson, USA).

An OJIP curve of transient chlorophyll a fluorescence and the activity of the enzymes catalase (CAT), peroxidase (POX) and superoxide dismutase (SOD) was prepared for data obtained at 100 days after emergence.

OJIP is a tool for the analysis of transient change in chlorophyll fluorescence kinetics and provides detailed information regarding the structure and function of the photosynthetic apparatus, particularly photosystem II (Gonçalves at al., 2010). Phase (O-J) corresponds to the complete reduction of primary electrons from the photosystem II receiver (quinone). Phase (JI) corresponds to the transfer of electrons to $Q_{a} Q_{b}$, and stage (I-P) corresponds to the release of fluorescence (Abbaspoor and Streibig, 2005).

The activity of the antioxidant enzymes, i.e., superoxide dismutase, peroxidase, and catalase, was measured in leaf and root tissues, following the methodology compiled by Broetto (2014).

\section{Experimental design}

The experiment involved a completely randomized design, as the treatments were arranged in split-split-plot design included four levels of aluminium in the soil $(0.0,8.2,16.5$, and $24.0 \mathrm{mmol}_{\mathrm{c}} \mathrm{dm}^{-3}$ ). The split-plot were planted with four accessions of $J$. curcas to represent four towns in different regions of Brazil (P1 = Dourados, MS; P2 = Montes Claros, MG; P3 = Alta Floresta, MT; P4 = Petrolina, PE), and the split-splitplot represented the four times $(25,50,75$ and 100 days postemergence). Three replicates were used for each treatment, totaling 192 vessels, with four repetitions.

For the curve of transient chlorophyll $a$ fluorescence (OJIP) and enzyme activity, the treatments were arranged in split-plot, being four levels of aluminium in the soil and the four accesses of J. curcas.

\section{Statistical analysis}

The results obtained were tested for normality (using the Lilliefors test) and homogeneity (using the Bartlett test) for analysis of variance of the characteristics studied. Next, the data were statistically analyzed by the analysis of variance Ftest, and the $5 \%$ probability and statistically significant effect for the averages of the accessions were compared using Tukey's test. The average aluminium levels, age of plants, and interactions between the factors were adjusted by regression analysis to the $5 \%$ level of probability.

Data were analyzed using the statistical program SAEG 9.1. OJIP curve analysis of fluorescence for the treatments was conducted by comparing the averages of the curves for the different treatments.

\section{Conclusion}

In conclusion the photosynthetic metabolism reduced with increased levels of aluminium in the soil, regardless of the origin of genetic material, with lower root growth. The fluorescence characteristics of chlorophyll indicated that doses above 8.2 accentuated aluminium stress on plants from all accessions. The OJIP test confirmed the reduction in photochemical efficiency. The activities of CAT, POX and SOD increased in the presence of aluminium for accessions P3 and 
P4, indicating greater tolerance of these genotypes to aluminium stress conditions.

\section{Acknowledgments}

We acknowledge the CNPq (Conselho Nacional de Desenvolvimento Científico e Tecnológico) and Coordenação de Aperfeiçoamento de Pessoal de Nível Superior (CAPES) for the financial support and scholarship.

\section{Contribution of authors}

Conceptualization, Scalon L.Q. and Mota, L. H. S.; Methodology, Scalon S. P. Q.; Mota, L. H. S.; Dresch, D.M. and Silva, C.J.; Investigation, Scalon S. P. Q. and Mota, L. H. S.; Writing - Review and Editing, Scalon S. P. Q.; Mota, L. H. S. and Dresch, D. M.

\section{References}

Abbaspoor M, Streibig, JC (2005) Clodinafop changes the chlorophyll fluorescence Induction curve. Weed Sci. 53: 1-9.

Achten WMJ, Maes WH, Reubens B, Mathijs E, Singh VP, Verchot L, Muys B (2010). Biomass production and allocation in Jatropha curcas L. seedlings under different levels of drought stress. Biomass Bioenergy. 34: 67-676.

Behera SK, Srivastava P, Tripathi R, Singh JP, Singh N (2010) Evaluation of plant performance of Jatropha curcas L. under different agro-practices for optimizing biomass - A case study. Biomass Bioenergy. 34: 30-41.

Bolhàr-Nordenkampf $H R$, Long $S P$, Baker NR, Öquist $G$, Schreider U, Lechner EG (1989) Chlorophyll fluorescence as a probe of the photosynthetic competence of leaves in the field: a review of current instrumentation. Funct Ecol. 3:497514.

Broetto F (2014) Métodos de trabalho em bioquímica vegetal e tecnologia de enzimas. Coordenador: Fernando Broetto Botucatu: IBB, Cultura. Acadêmica, 2014. UNESP, São Paulo, $92 \mathrm{p}$.

Cupertino CFS, Oliveira LEM, Mesquita AC, Nascimento MN, Souza GA, Silva LTB (2016) Alterações morfofisiológicas da aplicação de metais pesados e alumínio em plantas jovens de seringueira. Rev Elet Cient. 2: 135-144.

Fietz CR, Fisch GF. O clima da região de Dourados, MS. Dourados: Embrapa Agropecuária Oeste, 2006. 32 p.

Gonçalves JFC, Silva CE, Guimarães DG, Bernardes RS (2010) Análise dos transientes da fluorescência da clorofila $a$ de plantas jovens de Carapa guianensis e de Dipteryx odorata submetidas a dois ambientes de luz. Acta Amazonica. 40: 8998.

Konrad MLF, Silva JAB, Furlani PR, Machado EC (2005) Trocas gasosas e fluorescência da clorofila em seis cultivares de cafeeiro sob estresse de alumínio. Bragantia. 64: 339-347.
Ma B, Gao L, Zhang H, Cui J, Shen Z (2012) Aluminium-induced oxidative stress and changes in antioxidant defenses in the roots of rice varieties differing in Al tolerance. Plant Cell Resp. 31: 687-696.

Macedo FL, Pedra WN, Silva AS, Barreto MCV, Mann RS (2011) Efeito do alumínio em plantas de Pinhão-manso (Jatropha curcas L.), cultivadas em solução nutritiva. Semina: Ciênc Agrar. 32:157-164.

Mehta P, Jajoo A, Mathur S, Bharti S (2010) Chlorophyll $a$ fluorescence study revealing effects of high salt stress on Photosystem II in wheat leaves. Plant Physiol Biochem. 48:16-20.

Novais RF, Neves JCL, Barros NF (1991) Ensaio Em Ambiente Controlado. In: Oliveira AJ, Garrido WE, Araújo JD, Lourenço $S$ (Coord.). Métodos de pesquisa em fertilidade do solo. Brasília: EMBRAPA-SEA. 189-253p.

Oukarroum A, Schansker G, Strasser RJ (2009) Drought stress effects on photosystem I content and photosystem II thermo tolerance analyzed using $\mathrm{Chl} a$ fluorescence kinetics in barley varieties differing in their drought tolerance. Physiol Plant. 137: 88-199.

Peixoto PHP, Matta FM, Cambraia J (2002) Responses of the photosynthetic apparatus to aluminium stress in two sorghum cultivars. J Plant Nut. 25: 821-832.

Pompelli MF, Barata LRM, Vitorino HS, Gonçalves ER, Rolim EV, Santos MG, Almeida-Cortez JS, Endres L (2010) Photosynthesis, photoprotection and antioxidant activity of purging nut under drought deficit and recovery. Biomass Bioenergy. 34: 1207-1215.

Pompelli MF, Ferreira DTRG, Cavalcante PPGS, Salvador TL, Hsie BS (2010b)Environmental influence on the physicochemical and physiological properties of Jatropha curcas L. seeds. Aust J Bot. 58: 421-427.

Ribeiro C, Cambraia J, Peixoto PHP, Fonseca Júnior M (2012) Antioxidant system response induced by aluminium in two Rice cultivars. Braz J Plant Physiol. 24: 107-116.

Silva DM, Santos KT, Duarte MM (2011) Eficiência fotoquímica em folhas do mamoeiro (Carica papaya L.) cv. Golden durante o estádio reprodutivo e caracterização da ontogenia dos frutos. Rev Bras Frut. 33: 1066-1073.

Xu FJ, Li G, Jin CW, Liu WJ, Zhang SS, Zhang YS (2012) Aluminium induced changes in reactive oxygen species accumulation, lipid peroxidation and antioxidant capacity in wheat root tips. Biologia Plantarum. 56: 89-96.

Yamamoto Y, Kobayashi Y, Devi SR, Rikiishi S, Matsumoto H (2002) Aluminium toxicity is associated with mitochondrial dysfunction and the production of reactive oxygen species in plant cells. Plant Physiol. 128: 63-72.

Yang M, Tan L, Xu Y, Zhao Y, Cheng F, Ye S, Jiang W (2015) Effect of low ph and aluminium toxicity on the photosynthetic characteristics of different fast-growing eucalyptus vegetatively propagated clones. Plos One. 10: 115. 